\title{
Debatten internationaliseres
}

\section{Nye stemmer om bogen »Idrættens tredje vej« - i kronologisk orden}

\section{Samlet af Henning Eichberg}

»En række nye idrætspolitiske emner er blevet sat på dagsordenen i løbet af 1994. Blandt andet har debatbogen 'Idrættens tredje vej', som er udkommet som et led i kulturminister Jytte Hildens store kulturpolitiske redegørelse, præget den idrætspolitiske debat ...

Foreningsidrættens grundlæggende værdier er i løbet af året blevet sat under pres. Forårets store debatbog, 'Idrættens tredje vej', foreslog oprettelsen af et halvstatsligt idrætsfond, som skulle støtte alt det uorganiserede og eksperimenterende, som organisationerne og foreningerne ifølge forfatterne ikke evner til at opfange.

Bogens forfattere lagde samtidig et så unuanceret idrætssyn for dagen, at mange idrætsledere havde svært ved at finde overensstemmelse mellem bogens mange påstande og teoretiske konstruktioner og virkelighedens mangfoldige idrætsbillede ...

Som et konstruktivt bidrag til såvel debatten om 'Idrættens tredje vej' som forslaget om et idrætsråd, har DIF derfor besluttet at udarbejde en opfølgningsbog, som tager fat dér, hvor 'Idrættens tredje vej' slap ... DIF forventer bogen færdiggjort i foråret 1995.«

Kai Holm i DIF-bestyrelsens årsberetning, Idratsliv, nr.19/18.november 1994.

»... aufsehenerregend ... gehörte zu den Höhepunkten des Symposiums ... In seinem kulturanthropologisch, soziologi- schen Referat beleuchtete er (Henning Eichberg) die Einbettung des Sports in die Kulturpolitik Dänemarks. Dies tat er mit Hilfe der Untersuchung 'Der dritte Weg des Sports', welche vom dänischen Kulturministerium in Auftrag gegeben wurde und deren erst kürzliche Veröffentlichung auf dem Büchermarkt Dänemarks bereits vergriffen ist. Vor dem Hintergrund unterschiedlicher dänischer Teilkulturen können in Dänemark drei vorherrschende Sportmodelle unterschieden werden. Darunter fallen der hegemoniale Leistungssport auf der Grundlage von Spezialverbänden, der gesundheitspädagogische Fitness- und Wohlfahrtssport und der 'volkliche' Sport lokaler Kultur- und Netzwerkarbeit. Die Zukunftsszenarien des Sports entsprechen somit den von dänischen Sozialforschern entworfenen gesamtgesellschaftlichen Szenarien, einer auf Wettbewerb und Leistung ausgerichteten effektiven Gesellschaft, einer vom kooperativen Interessenausgleich konzipierten Konsensusgesellschaft und einer auf weitgehender kommunaler Selbstbestimmung aufgebauten dezentralen $\mathrm{Ge}$ sellschaft. Die Ergebnisse der Untersuchung widersprechen somit allen Versuchen, die die Entwicklung des Sports im Sinne einer fortschreitenden 'Ausdifferenzierung' oder 'Modernisierung' sehen.«

Mark Otto, Teknisk Universitet Chemnitz-Zwickau, om de tyske idratssociologers årsmøde »Modernisering og idrat «, $i$ DVS-Informationen, Deutsche Vereinigung 
für Sportwissenschaft, Hamburg, $n r$. 4/december 1994, s.50.

»Med dette (Duelund-udredningen - H.E.) må danskene være iferd med å overta svenskenes ry for å lage store og omfattende utredninger... et imponerende arbeide som, når det er avsluttet, vil være en gullgrube for kunnskap om kulturlivet i Danmark. ...

Blant delutredningene er rapporten om idrett svært omfattende, kanskje for stor. ... Fordelen med denne formen er tross alt at den viser samspillet mellom fysisk aktivitet og generelle samfunnsendringer. Boken inviterer til det 'tredje alternativ', dvs. at idretten skal organiseres desentralt med basis i lokale nettverk. En slik prioritering av selvforvaltningsprinsippet gjøres imidlertid uten å diskutere hvorvidt det står i motsetning til likhetsidealet.«

Marit Bakke, Universitetet $i$ Bergen, $i$ Politica, $26: 3$ (1994) 355-359. (Lighedsproblematikken behandles $i$ »Idrattens tredje vej« på side 194 og 246.)

»Diskussionen i forbindelse med 'Idrættens 3. vej《 illustrerer udmærket det debatniveau, der kendetegner idrætsorganisationerne, som - når det primært drejer sig om at fastholde deres egen uovertruffenhed tager udgangspunkt i en ofte nedgørende, usaglig kritik af modstanderen i stedet for at tage afsæt i sig selv. Man kan være enig eller ikke enig med Claus Bøjes artikel (i Gerlev Idrætshøjskoles årsskrift 1994), men hvorfor ikke betragte bogen som det, den er. Et spark bagi til den danske idrætskultur, der ikke har forstået at følge med samfundets udvikling (repræsentant for DFIF).

Hanne Petersen, tidligere naestformand $i$ DIF, i Dansk Ungdom og Idrat, nr. 6/23. februar 1995.
»Armod i idrcetsdebatten.

... Man kan mene om bogen, hvad man vil, men man kan ikke komme udenom, at idrætten hermed havde fået et oplæg til diskussion af idrættens fremtidige rolle.

På den baggrund kan det undre, at Kaj Holm indledte debatten på så lavt niveau. Det blev imidlertid forståeligt i lyset af den høring, som Idrættens Fællesråd efterfølgende tog initiativ til. Fra begyndelsen stod det klart, at forfatterne skulle have en ordentlig én på tuden for deres formastelighed. Deres forbrydelse bestod i at foreslå en uafhængig idrætsfond til varetagelse af den uorganiserede idræts interesser ...

Efter tur gik de på talerstolen for at gøre sig muntre over, at halvdelen af forfatterne aldrig har dyrket praktisk idræt og ikke kender lugten af sved i et omklædningsrum ...

Hvorom alting er, nogen velunderbygget debat om idrætskulturen kom aldrig i gang af den simple grund, at idrættens organisationer er interesse-organisationer. Og det, de primært interesserer sig for, er at styrke sig økonomisk. Tipsmidlerne er organisationernes grundlag ... (i 1991 ... 731 millioner kroner). I det lys skal man forstå idrætsdebattens armod. Der er simpelt hen for store $\varnothing$ konomiske interesser på spil, til at man kan interessere sig for idrætten som sådan.«

Verner Mфller, forsker ved Institut for Idrcet på Odense Universitet, i Fyens Stiftstidende, 6.marts 1995.

»Ideologiske skyttegrave.

... man skal passe på med at tro, at den hellige grav er velforvaret, så længe der er en elite, som kan skabe opmærksomhed om idrætten. Man skal også passe på med at gå i den modsatte grøft og konkludere: At eliten intet har at give bredden, at det er en ren statistisk tilfældighed, at håndbold 
og fodbold oplever fremgange i kølvandet på opsigtsvækkende resultater, og at sammenhængen af elite og bredde snarere er negativ.

Sidstnævnte form for konklusioner er desværre ved at blive en mere og mere udbredt tendens i den offentlige debat om idrætspolitikken. Senest illustreret ved bogen 'Idrættens tredje vej', hvor forfatterne $i$ et opg $\varnothing r$ med tesen om idrættens enhed føler sig nødsaget til at afvise enhver form for positiv afsmitning fra eliten til den resterende del af idrætten. Forfatterne begår derved en klassisk fejltagelse. I ren og skær iver efter at bekæmpe ét unuanceret og ideologisk betonet billede af idrætten nemlig dogmet om, at elite pr. automatik skaber bredde - opstiller de et andet lige så unuanceret og ideologisk betonet dogme: At eliten intet godt har at give bredden, snarere tværtom... Lad os komme væk fra de ideologiske skyttegrave og give plads til en mere nuanceret debat.«

Morten Molholm Hansen i Idratsliv, nr. 5/10. marts 1995.

»Årets mest omtalte og udskældte idrætspolitiske debatbog.«

Danmarks Idrats-Forbunds Årbog 1994. 1995, s. 34

»Idrætssystemet har udviklet sig til et virvar af mere eller mindre formaliserede idéudvalg og støtteordninger. Der er derfor behov for forenkling og mere overskuelighed i de kulturpolitiske intentioner og i de bevillingsmæssige muligheder til idrætten, konkluderer kultursociologen Peter Duelund i den afsluttende redegørelse i serien Kulturens Politik.

Forslaget fra bogen »Idrættens tredje $v e j \ll$ om at oprette et idrætsråd som et supplement til de bestående idrætsorganisationer, bliver som det eneste konkrete forslag gentaget i Peter Duelunds afsnit om idrætten.«

Torben Elsig-Pedersen i Dansk Ungdom og Idrat, nr.12/13.april 1995.

»Misvisende kritik.

Et af kritikpunkterne imod den organiserede idræt i den seneste idrætspolitiske debat har været idrætsorganisationernes påståede manglende evne eller vilje til at varetage nye idrætsformers behov og interesser. Spørgsmålet er imidlertid, hvor rimelig denne kritik er.

I kultursociolog Peter Duelunds afsluttende rapport 'Den Danske Kulturmodel' foreslår Duelund på baggrund af debatbogen 'Idrættens tredje vej', at der oprettes et særskilt idrætskontor med tilknyttet konsulentvirksomhed i Kulturministeriet eller en uafhængig og sagkyndig instans, der skal sikre en mangfoldig idrætsudvikling, herunder de nye idrætsformer, som ikke i dag varetages af idrættens hovedorganisationer.

Hverken Duelunds afsluttende rapport eller 'Idrættens tredje vej' er særlig meddelsom, når det gælder konkrete eksempler på, hvilke nye idrætsformer, som svigtes af organisationerne. Og det er måske ikke så underligt. For i den analyserede periode 1960-1994 er antallet af specialforbund under DIF blevet næsten fordoblet. Dertil kommer, at en række nye aktiviteter er kommet ind under DIF enten ved at blive associeret/fusioneret med et nært beslægtet forbund eller ved at blive en integreret del af et specialforbunds aktivitetsområde.

DIF og specialforbundene har faktisk altid været meget åbne over for at optage nye forbund - så åbne, at udenforstående til tider har rystet på hovedet over, at idrætsgrene med en meget begrænset udbredelse har fået det blå stempel som selvstændige forbund. Filosofien har imidlertid været, at 
tvangssammenslutninger af idrætsforbund risikerer at $\varnothing$ delægge en afgørende drivkraft i idrætten: Nemlig de mange frivilliges optagethed af deres idrætsgrens særegenheder ...

Det står altså ikke på dette område så galt til med den organiserede idræts omstillingsevne, som nogen gerne vil give indtryk af. Kritikere kan have ret i, at der måske går et stykke tid, førend forbund og klubber får øjnene op for nye behov og interesser i befolkningen. Men er det så unaturligt? Og er det i $\varnothing v$ rigt ikke en meget sund politik først at vurdere, om en 'modedille' har greb nok i befolkningen til at blive til andet end blot en døgnflue, førend hele det organisatoriske apparat sættes i sving?

En meget større udfordring for den organiserede idræt består derimod i at få skabt anderledes samværs-, trænings- og konkurrenceformer for især børn og unge inden for en række eksisterende idrætter. Denne aldersgruppe bør fortsat være både det offentliges og idrætsorganisationernes væsentligste målgruppe...«

Morten Mølholm Hansen i Idratsliv, nr. 11/9. juni 1995.

»I Japan har vi behov for en ny teoretisk indsigt i kropskulturen med det væsentlige perspektiv at sammentænke liv, idræt og oplysning. Det er et spørgsmål om filosofi. I 'Idrættens tredje vej' af Henning Eichberg og Claus Bøje er den tredje vej nøglen til at tænke kropskulturens teori gennem en differentiering mellem: 1 . rekord- og resultatsorientering - produktivisme, 2. idræt for alle, pædagogik, sundhedsorientering opmærksomhed på ens egen krop, 3. rytme, højtid, traditionel idræt, leg og friluftsliv - den dialogiske krop på grundlag af kropserfaring.

Sammenligner man den tredje vej med elitesporten og sundhedsidrætten, så intro- ducerer den en ny dimension i Japan. Eichberg og Bøje understreger, at dens væsentlige træk er menneskers forhold til hinanden og deres identitetsdannelse på grundlag af fælles udfoldelse, glæde og kropserfaring. «

Satoshi Shimizu i Journal of Health, Physical Education and Recreation, Tokyo, 45: 5-6 (1995) 421-423 og 495-498.

\section{»Dansk bok stakar ut vägen till framtiden.}

... Efter andra världskriget har idrottens utbredning i Västeuropa i varierande grad blivit en statslig angelägenhet. I Sverige skapades ett bidragssystem till föreningar och förbund. Parollen om 'idrott åt alla' myntades i enlighet med den dominerande politiska och centralistiska jämlikhetsprincipen, men det blev allt tydligare att det existerade olikheter. Breddidrotten kom i ett spänningsförhållande till elitidrotten. Dogmen att bredden skapar eliten och eliten skapar bredden blev allt ihåligare ...

Henning Eichberg är en tysk idrottsforskare verksam i Danmark. Han har tillsammans med Claus Bøje på det danska kulturdepartementets uppdrag gjort en idrottspolitisk utredning. I den lanceras en analysmodell som fått stort genomslag i den idrottspolitiska debatten. Enligt denna modell består idrotten inte av två utan tre poler som orienterar sig mot prestation, sundhet och kroppsupplevelse. Historiskt är ordningen egentligen tvärtom. Kroppsupplevelsen är lekens ursprung, som i sin tur utvecklades till den pedagogiska gymnastikrörelsen. Gymnastikrörelsen kom därefter att utveckla en gren mot den mer prestationsinriktade tävlingsidrotten.

Där prestationsidrott står for frihet att överdriva och bryta gränser i ett fyrkantigt, standardiserat, kontrollerat och specialiserat rum för produktion av rekord, står sundhetsidrott för jämlikhet och reproduktion av arbetskraft. Kroppsupplevelsen står 
för det tredje elementet i franska revolutionens demokratiprinciper: broderskap. Kalla det gärna även systerskap. Andra element är social gemenskap och avsaknad av produktion...

Bøje och Eichberg anger indirekt även skilda tidsbegrepp hos de olika polerna. Prestationsidrotten slår rekord med samma logik som företag strävar efter allt kortare produktionstider. Omsättning och vinst växer linjärt med tiden, det finns inget naturligt slut. För prestationsidrottens del betyder det kris om rekorden inte längre kan slås. Sundhetsidrottens reproduktion antyder en cirkulär tidsstruktur, där kroppens återhämtning är ständigt återkommande tema. För kroppsupplevelsen däremot härskar spontaniteten och nuet. Ibland kallar man det punkttid.

Den prestationsorienterade delen av idrotten har svårast att överleva av egen kraft, trots att den har varit dominerande under 1900-talet. Kroppsupplevelsens ökande betydelse kan avläsas i den nya publikkultur som har utvecklats under senare år. Inspirerade av Köpenhamns pingstkarneval har den danska idrottspubliken utvecklat liknande former och blivit 'roligans', som kontrast mot de fruktade engelska 'hooligans'. Denna gräsrötsrörelse har snabbt spridits till andra länder. Halvmaran i Göteborg, som är mer sundhetsorienterad idrott, har också anammat mycket av karnevalskulturen.

Bøje och Eichberg föreslår i sin utredning att det etableras en idrottsfond, som ska stimulera skapandet av idrottsformer som är riktade mot kroppsupplevelsepolen i den trialektiska modellen. Trots att det skulle handla om en mycket blygsam andel av den samlade idrottsanslaget, har förslaget väckt kraftiga protester hos de stora etablerade idrottsorganisationerna.

Hur skulle en liknande debatt kunne frodas i Sverige, med Riksidrottsförbundet som monopolorganisation och där myten om bredd och elit krampaktigt hålls vid liv? Vem kan lägga pussel när alla bitar ser likadana ut? «

Christer Wigerfelt i Fotavtryck, Göteborg, nr. 3/oktober 1995.

»Idrottens många vägar - några danska forskningsrön.

Den danska idrottsforskningen följer ofta helt andra linjer än dem vi påträffar i Finland, Sverige och Norge. Därför kan det vara av interesse för många läsare att stifta bekantskap med några arbeten ur den 'danska skolan' ...

Som ett led i en kulturpolitisk utredning ombads Claus Bøje och Henning Eichberg att skriva om idrottens utveckling 19601994. Resultatet blev den omtvistade boken 'Idrættens tredje vej'... För en offentlig utredning har boken fått kanske ovanligt livlig respons och det verkar åtminstone som om det danska idrottsfolk skulle ha läst boken... De ledande danska idrottsorganisationerna (har) inte set med blida ögon på utredningen. De gillar inte den kritiska syn på på elitidrotten som författarna presenterar...

Om man får tro kritiken, så rör vi oss här i en pseudo-forskningsmiljö, där författarna väver in det hela i en oklar romantisk-utopisk revolutionsförväntning, presenterar romantiska drömmerier om den stora kroppsrevolution som omstörtar det dödsdömda industrisamhället och kommer fram till ett varmt och kroppsligt fantasifoster som idrottsfolket inte kan använda konstruktivt ...

För en utomstående läsare, utan ingående kunskap om danska idrottsförhållanden, verkar kritikerna i första hand något överkänsliga. Boken ter sig inte så provocerande vid en första genomläsning ... 
De avslutande kapitlen med framtidsvisioner och tolkningar av utvecklingstrender (er) av mera generellt intresse. De finska idrottsorganisationerna och beslutsfattarna kan ha desto större utbyte av att jämföre danska förhållanden med våra egna, t.ex. med tanke på fördelingen av tipsmedel mellan idrott, kultur och andra målgrupper.

Utan att närmare gå $\mathrm{i}$ detaljerne $\mathrm{i}$ det danska idrottsudövandet, kan man ur de statistiska tabellerna utläsa vissa intressanta trender... förskjutningarna i åldersstrukturen bland idrottsutövarna under perioden 1960-1994... Denna utveckling inverkar följaktligen på grenvalget... Författarna debatterar i de avslutande kapitlen vad dessa utvecklingstrender kan ha för inverkan på idrottsorganisationernas och, i ett bredare perspektiv, på kulturpolitikens prioriteringar - idrott är ju kultur, som vi alla vet.«

Kenth Sjöblom i Suomen Urheiluhistoriallisen Seuran Vuosikir jalFinlands Idrottshistoriska Förenings Årsbok 1995, Joensuu 1995, s. 247-258.

»Danmark är inte Sverige. Sundet markerar skiljelinjen mellan gemyt och allvar, 'en lille en' och nykterhetsrörelsen, pluralism och monopol i organisationsliv och åsikter. Skillnaden kan även spåras i idrottslivet: roliganer mot huliganer, alternativa organisationer mot enhetslösning, grundläggande principdebatt mot symtomdebatt. Danmark tar nog dessutom sin tävlingsidrott med mindre allvar än Sverige ...

Syftet (med 'Idrættens tredje vej') är principdebatt och information. Boken för fram djärva, konstruktiva, bitvis fantasifulla åsikter och förslag som sedan 70-talet florerat i Danmark men varit sällsynta eller frånvarande i Sverige ...

Det räcker långt att gå över sundet. Vi behöver insikt om att den svenska idrotts- modellen inte är självklar - lika litet som den svenska samhällsmodellen i stort.

'Idrættens tredje vej' har väckt stor uppmärksamhet i dansk dags- och fackpress. Bedömningarna är starkt polariserade, somliga berömmande, andra förkastande. Varför? Grundorsaken är att de två författarna, hemmahörande på en till Gerlev idrottsfolkhögskola lokaliserad forskningsorganisation (Idrætsforsk), utmanar den existerande danska idrottsmodellen. Team Danmark och dagens tävlingsidrottsideal sätts i fråga, alternativ diskuteras.

Vad är det centrala i den danska debattboken? Kritiken mot dagens tävlingsidrottsmodell har redan nämnts. Det hävdas med exempel på anslagstilldelning, organisatorisk sega strukturer $\mathrm{m} m$ att denna modell präglar den offentliga synen och satsningen på idrott orimligt mycket. Med andra ord har politikerna, främst genom gällande lag om elitidrott från 1984, gynnat denna del av idrottslivet på andra delars bekostnad ...

Enkelt plockade debattpoäng finner de två författarna i cirkusbegreppet. De påpekar med rätta hur tävlingsidrotten till en början markerade en skarp skiljelinje mellan cirkusartisterna och de långt mer högtstående egna idrottsamatörerna. Nu börjar cirkusen bakvägen - eller rentav genom huvudentrén? - komma i idrottslivet. Den ekonomiska logiken gör att de märkliga former av brottning som alltmer visas på TV anger utvecklingens väg in i framtiden. Vem kan med övertygelse avvisa denna, dystra vision som alldeles orealistisk?

Författarna går emot den endimensionella föreställningen om idrotten som ett harmoniskt helt - samma fenomen som levt så starkt i Sverige och väl fortfarande är officiell uppfattning här. Enligt denna föreställning lever breddidrott och elitidrott i lycklig symbios, går naturligt in i 
varandra och inrymmer inte komplicerade motsatsförhållanden. Gentemot denna idyllisering av förhållandena förnekar man i boken allt tal om enkla, positiva samband mellen bredd och topp, hälsa och prestation.

Mycket och djupgående ifrågasätts alltså dagens danska idrottsliv. Här lyckas författarna i stora stycken väl. Svårare har de att på övertygande sätt peka ut alternativen. Man kan inte av visionärer fordra det omöjliga i fråga om tydlighet och konkreta förslag - men mera än vad som bjuds. En viktig punkt $\mathrm{i}$ visionen om något nytt och bättre är den s k trialektik. Det är tredelning av idrottslivet...: prestationsmodellen, hälsomodellen, kroppserfarenhetsmodellen.

Författarna sympatiserar med de två senare modellerna och påpekar att de går lätt och naturligt att kombinera. En sådan kombination kunde bli ett slagkraftigt alternativ till prestationsmodellen (dvs Team Danmark och motsvarande). I stället talar man om 'idrættens tredje vej' som något så viktigt att det fått ge boken dess titel. Men här kommer svårigheterna. Läsaren får aldrig något rejält grepp om denna väg. Författarna är själva medvetna om problemet. Den tredje vägen är enligt dem 'först och främst av metodisk art, en filosofisk synvinkel'. Vagheten er påfallande. Här ligger den mycket stimulerande bokens stora svakhet.«

Jan Lindroth, professor ved Stockholms Universitet, i Svensk idrott, $n r$. 11/november 1995. 